\title{
A Piecemeal Description of Streptomyces griseus (Krainsky) Waksman and Henrici
}

\author{
By RUTH E. GORDON AND ANN C. HORAN \\ Institute of Microbiology, Rutgers, The State University, \\ New Brunswick, New Jersey, U.S.A.
}

(Accepted for publication I8 July I967)

\begin{abstract}
SUMMARY
Forty-six of the 48 strains named Streptomyces griseus in our collection have in common a distinctive pattern of properties and are believed to represent a recognizable taxonomic group, or aggregate, of this polytypic species. Seventy-seven additional strains bearing $5 \mathrm{I}$ different species names were found to possess the same pattern of characteristics. The distinguishing properties of this aggregate are described and compared with those of $S$. albus, $S$. fradiae and $S$. somaliensis.
\end{abstract}

\section{INTRODUCTION}

Early in this study of the streptomycetes wide variation was observed among cultures of individual strains not only in their pigmentation but also in their formation of aerial hyphae, sporulation and the fragmentation of their substrate hyphae (Gordon \& Mihm, 1962). Certain physiological properties, on the other hand, were shared by the parent strains and their soft fragmenting variants. Because the basic taxonomic unit (designated here by the old-fashioned term 'species') can be recognized in different ways, a search was begun for a group of relatively stable characters by which each species might be described and differentiated from the other species of streptomycetes and nocardias in our collection.

According to the criteria investigated, certain species, typified by Streptomyces fradiae, were comparatively homogeneous and distinct; either all the strains, or nearly all the strains, gave the same reaction to each test applied (Gordon, 1967). A distinguishing pattern of characters for recognizing $S$. fradiae was thus easily found. Other species were more heterogeneous, or polytypic, and were, apparently, composed of aggregates of strains with intermediate strains connecting the aggregates. S. griseus (Krainsky, I9I4) Waksman \& Henrici (I948) is an example of a polytypic species, and its composition, as represented in our collection, confirmed Pridham's (1964) description of $S$. griseus as a 'species comprising many sub-species'.

On the basis of physiological properties, 46 of the 48 strains named Streptomyces griseus in the Institute of Microbiology, Rutgers, The State University, New Jersey (IMRU), collection were relatively similar and are representative of a single aggregate joined to other aggregates by intermediate strains. These 46 strains have been kept as separate strains, although some are duplicates maintained for several years in other laboratories and some are variants developed for specific purposes. The pattern of reactions by which these 46 strains can be recognized, and a list of other strains in this IMRU collection with the same pattern of characters are presented. 


\section{METHODS}

The 123 strains listed in Tables I and 2 and the strains examined by Gordon (I966, 1967) were compared by means of observations and tests described in the same reports. In addition, the following tests were used.

Hydrolysis of hippurate. Cultures were prepared in hippurate broth (tryptone, Io g.; beef extract, 3 g.; yeast extract, I g.; glucose, I g.; $\mathrm{Na}_{2} \mathrm{HPO}_{4}, 5 \mathrm{~g}$.; Na hippurate, Io g.; distilled water, I000 $\mathrm{ml}$.). After 6 weeks of incubation at $28^{\circ}$, I ml. of each culture, as free from clumps of growth as possible, was mixed with $\mathrm{I} \cdot 5 \mathrm{ml}$. of $50 \%$ $(\mathrm{v} / \mathrm{v})$ sulphuric acid. The appearance of finely divided crystals in the acid mixture after $4 \mathrm{hr}$ at room temperature indicated the presence of benzoic acid (Baird-Parker, 1963). When the identity of the crystals was in doubt, their melting point was compared with that of benzoic acid.

Oxidation of glucose. The oxidative or fermentative utilization of glucose was determined by the Hugh \& Leifson (1953) test. The basal medium (peptone, $2 \mathrm{~g}$.; $\mathrm{NaCl}, 5 \mathrm{~g}$.; $\mathrm{K}_{2} \mathrm{HPO}_{4}, 0.3 \mathrm{~g}$.; agar $3 \mathrm{~g}$. $0.04 \%$ (w/v) aqueous solution of bromcresol purple, I $5 \mathrm{ml}$; distilled water, $1000 \mathrm{ml}$; $\mathrm{pH} 7 \cdot \mathrm{I})$ was tubed $(7.5 \mathrm{ml} . / 16 \mathrm{~mm}$. diam. tube), autoclaved and quickly cooled. Before the agar solidified, $0.5 \mathrm{ml}$. of $15 \%(\mathrm{w} / \mathrm{v})$ aqueous solution of glucose, also sterilized by autoclaving, was added to each tube. As soon as the agar hardened, duplicate tubes were inoculated by stabbing from a I0- to I4-day culture in glucose broth; one tube was then sealed with a mixture of petroleum jelly and paraffin (paraffin, $60 \%(\mathrm{w} / \mathrm{w})$; petroleum jelly, $40 \%(\mathrm{w} / \mathrm{w})$ ). During the first $24 \mathrm{hr}$ of incubation, some cultures had to be resealed by heating the glass around the jelly in a small flame. The cultures were incubated at $28^{\circ}$ and observed at 7 and 28 days. A culture that grew both in the aerobic and the anaerobic tubes, but formed the acid colour of the indicator only in the aerobic tube was recorded as oxidizing glucose. A culture that grew and formed the acid colour of the indicator both in the aerobic and the anaerobic tubes was recorded as fermenting glucose. A culture that grew in both tubes but did not change the colour of the indicator was recorded as not attacking glucose in the medium of Hugh \& Leifson.

Resistance to salicylate. A tube of glucose broth (peptone, $5 \mathrm{~g}$.; beef extract, $5 \mathrm{~g}$.; yeast extract, $5 \mathrm{~g}$.; glucose, $5 \mathrm{~g}$.; distilled water, $1000 \mathrm{ml}$.) and a tube of glucose broth containing $0.2 \%(\mathrm{w} / \mathrm{v}) \mathrm{Na}$ salicylate were inoculated from a Io- to I4-day culture in glucose broth with a loop $2 \mathrm{~mm}$. outside diameter. The tubes were examined immediately and those containing inoculum that might be mistaken for growth were replaced. Growth of the cultures was observed after 7 and 28 days of incubation at $28^{\circ}$. This test was suggested by the method of Tsukamura (1962).

Utilization of benzoate, lactate and oxalate. Modifications of Koser's (1924) citrate agar were made by adding $2 \mathrm{~g}$. $\mathrm{Na}$ benzoate, $\mathrm{Na}$ lactate or $\mathrm{Na}$ oxalate to: $\mathrm{I}$. $\mathrm{NaCl}$, 0.2 g. $\mathrm{MgSO}_{4} \cdot 7 \mathrm{H}_{2} \mathrm{O}$, I g. $\left(\mathrm{NH}_{4}\right)_{2} \mathrm{HPO}_{4}, 0.5$ g. $\mathrm{KH}_{2} \mathrm{PO}_{4}$, I 5 g. agar, I000 ml. distilled water, $20 \mathrm{ml} .0 .4 \%(\mathrm{w} / \mathrm{v})$ phenol red solution. The $\mathrm{pH}$ value of each medium was adjusted to ensure a slightly acid colour of the indicator after autoclaving. Cultures on slopes of each medium were observed for the alkaline colour of the indicator after 7 and 28 days of incubation at $28^{\circ}$.

Determination of diaminopimelic acid $(D A P)$. The method of Becker, Lechevalier, Gordon \& Lechevalier (1964) was used to establish the form of DAP in hydrolysates of the whole organisms. 


\section{RESULTS}

After 5 days of incubation, cultures of the strains (Tables I, 2) grown on glycerol agar and stained by a modified Ziehl-Neelsen method were composed of short or long slender branching filaments that did not retain the carbol fuchsin. In some cultures the filaments were vacuolated, in others they were broken into uneven fragments or bacillary forms. Spores, when formed on the glycerol agar, appeared as spherical or oval bodies.

Table I. Reference strains of Streptomyces griseus (Krainsky)

\section{Waksman \& Henrici}

Laboratory no.

3326
$3326 \mathrm{a}$
$3326 \mathrm{~b}$
3378
3463,3464
$3464 \mathrm{a}$
3475
$3478,348 \mathrm{I}$
3480
$3492-3494,3498$
3496,3495
3499
3510
3511
3512
3523,3524
3527
3533
$3536-3539$
3546
3563
$3567 \mathrm{a}, 3567 \mathrm{~b}$
3570
$3586-3589$
3616
3620,3621
3646
3734
3754
3903
A10137

Source, strain name or number

N.J. Agr. Exp. Station (Waksman \& Curtis 360)

Centraalbureau voor Schimmelcultures (CBS) (Waksman \& Curtis 360)

A. Kelner, Biological Lab., Cold Spring Harbor, N.Y. (mutant I of Waksman \& Curtis 360)

F. A. Wolff, Duke Univ. (Yucatan)

N.J. Agr. Exp. Station (I8-I6, soil; D-I, chicken's throat)

N.J. Agr. Exp. Station (sporulating variant of D-I)

H. W. Anderson, Univ. of Ill. (variant 42.1 of 4 )

N.J. Agr. Exp. Station (25-G, peat; 22, soil)

Schenley Labs., Inc., Lawrenceberg, Ind. (SL-842)

N.J. Agr. Exp. Station (variants I, 9, 19 and $C_{1}$ of I 8-I6)

N.J. Agr. Exp. Station (4 and rhodomycetin producing variant of 4 )

C. H. Reilly, N.J. Agr. Exp. Station ( $\mathrm{C}_{3}$, a streptomycin producing variant of D-I)

W. Garson, N.J. Agr. Exp. Station (HF, cow manure)

Parke, Davis and Co., Detroit (04506)

N.J. Agr. Exp. Station (2 PR, a phage-resistant variant of 3475)

Merck and Co., Rahway, N.J. (7 R2557 and unnumbered); CBS 3496 and 3493)

N.J. Agr. Exp. Station (Mexican soil)

A. B. Kupferberg, N.J. Agr. Exp. Station (3I)

H. Umezawa, Nat. Inst. of Health, Tokyo (S-1, S-2, S-3 and S-4)

F. Bustinza, Univ. of Madrid (Z)

W. Gold, N.J. Agr. Exp. Station; Univ. of Wis.

N.J. Agr. Exp. Station (intestine of earthworm)

H. A. Lechevalier, N.J. Agr. Exp. Station (C I35, produces candicidin)

R. S. Weiser, Univ. of Wash. (214, 305, 1260 and 2017)

P. P. DeSomer, Rega Inst., Louvain (R 33, a variant of 3464)

H. E. Bailey, Wayne Univ. (I03 and I05)

R. G. Benedict, U.S. Dept. Agr., Peoria, Ill. (NRRL B-683)

J. Ehrlich, Parke, Davis and Co., Detroit (A 4903-PD 04797-NRRL 2426)

H. B. Woodruff, Merck and Co., Rahway, N.J. (L-I I 8 MA-45)

H. A. Lechevalier, Rutgers Univ. (LP-I6, produces geosmin)

American Type Culture Collection (ATCC) (roI37); S.A. Waksman (4)

On soil extract and Bennett agars, the colonies were densely or loosely filamentous. The substrate hyphae were extensive, fine, wavy, branching and intertwined with the substrate hyphae of adjacent colonies. The aerial hyphae varied from sparse to abundant, straight to loosely coiled, and short tolong, intertwining sometimes with the aerial hyphae of adjacent colonies. The aerial hyphae of some cultures branched in clusters or whorls. During the I4-day incubation chains of bead-like spores were formed.

Macroscopically the cultures on yeast dextrose agar at 7 days were abundant and spreading and finely or coarsely wrinkled or flat. The growth was cream- 


\section{Table 2. Strains identified as Streptomyces griseus (Krainsky, I9I4) Waksman \& Henrici (1948)}

Laboratory no. 3845

$4 \mathrm{I} 3$

3765

3347

3007

506

N 3258, N 4520

3301

676

3856

A 6855

A 6245

505

A 4919

5 II

$638,712,713$

699

3049

3861

N 7807

3005, 3006

3019

$336 \mathrm{I}$

3448

3462

3307

$3309 \mathrm{~A}$

$38 \mathrm{II}$

3312

3593

A 4879

3416

3758

33I3A, 33 I3 B

3657

3036

3316

$367 \mathrm{I}$

3590

3068

3325

3328

3329
Name when received, source, and strain name or number

Actinomyces cyaneofuscatus Kudrina (1957); G. F. Gauze, Inst. of Antibiotics, Moscow (92/54)

A. keratolytica; J. M. Coffey, N.Y. State Dept. of Health (5229)

A. longissimus Krassil'nikov (1941); H. J. Kutzner, Inst. f. Biochemie des Bodens, Braunschweig-Volkenrode, Germany (I 16); M.S Todorovič

* A. roseus Krainsky (I9I4); N.J. Agr. Exp. Station

A. sulphureus; N.J. Agr. Exp. Station

Nocardia alba; T. Thibault, Inst. Pasteur, Paris

$N$. asteroides; NCTC $(3258,4520)$

N. farcinica; N.J. Agr. Exp. Station; CBS

N. haemolytica; E. N. Azarowicz, Univ. of Calif. (19)

N. italica Spalla, Amici \& Bianchi (196r); A DiMarco, Farmitalia, Milan (soil)

N. leishmani; ATCC (6855); BCTC (658)

N. madurae; ATCC (6245); C. W. Emmons (9902)

$N$. odorifera (Rullmann, I895) Castellani \& Chalmers (1913); P. Thibault

N. sylvodorifera; ATCC (4919); A. Castellani

N. violacea (Rossi-Doria, I 89I) Chalmers \& Christopherson (19I6); P Thibault Nocardia spp ; D. B. Tilden, Chicago Zoological Park (lung of a kangaroo, lung lesion of a sitatunga, lung of a black-tailed deer)

Nocardia sp.; C. W. Emmons, Nat. Inst. of Health, Bethesda, Md. (9940); A. L. Carrion (mycetoma)

Streptomyces acidoresistans; N.J. Agr. Exp. Station; Král Collection

S. albidoflavus (Rossi-Doria, I89I) Waksman \& Henrici (1948); P M. Arnow, Rutgers Univ.; H. Okada

S. albus; NCTC (7807); W. R. Maxted

S. albus; N.J. Agr. Exp. Station; CBS; H. W. Wollenweber (potatoes)

S. albus; N.J. Agr. Exp. Station; CBS

S. albus; N.J. Agr. Exp. Station

$S$. albus; M. Welsch, Univ. de Liège

S. albus; C. H. Meredith, Glenleigh Lab., Highgate, Jamaica, B.W.I. (I I, anatgonistic to Fusarium oxysporum cubense)

$S$. annulatus; N.J. Agr. Exp. Station; CBS

S. aureus (Waksman \& Curtis, 1916) Waksman \& Henrici (I948); N.J. Agr. Exp. Station

S. baarnensis Pridham, Hesseltine \& Benedict (1958); Lederle Labs., Pearl River, N.Y.; CBS

$S$. californicus (Waksman \& Curtis, I9I6) Waksman \& Henrici (1948); N.J. Agr. Exp. Station

S. californicus; H.B. Woodruff, Merck and Co., Inc. Rahway, N.J. (5I R 3639)

S. candidus; ATCC (4879); S. A. Scudder (23314)

$S$. candidus; N.J. Agr. Exp. Station; ATCC (4878)

$S$ cavourensis Waksman (196I); R. Craveri, S. A. Montecatini, Milan (829, Linate)

S. cellulosae (Krainsky, 19I4) Waksman \& Henrici (1948); N.J. Agr. Exp. Station (variants of 3313)

S. chrysomallus Lindenbein (1952); K. B. Raper, U.S. Dept. Agr., Peoria, Ill. (NRRL 2250); Schenley Labs., Inc.

S. erytheus (Waksman, I923) Waksman \& Henrici (I948); CBS

S. exfoliatus (Waksman \& Curtis, 1916) Waksman \& Henrici (1948); CBS (Waksman \& Curtis)

S. flavochromogenes (Krainsky, 19I4) Waksman \& Henrici (1948); Heyden Chemical Corp., Princeton, N.J. (8)

$S$. gougeroti (Duché, 1934) Waksman \& Henrici (1948); CBS

S. griseobrunneus Waksman (196I); N. J. Agr. Exp. Station (218)

S. griseolus (Waksman, 1923) Waksman \& Henrici (1948); N.J. Agr. Exp. Station.

S. halstedii (Waksman \& Curtis, I916) Waksman \& Henrici (1948); N.J. Agr. Exp. Station

S. intermedius; H. W. Wollenweber, Forschungs Inst. f. Kartoffelbau, Berlin 
Table 2. (contd.)

Laboratory no.

3330

3331

3332

3334

3677

3686

3374

3344

3689

3350

3371

3351

3029

3352

A 10246

3375

N 3236

3418

3367

A II 86 I

3372

3690

A 6867

$58 \mathrm{I}$

985

3069

3482

N 4523

33 I I

Name when received, source and strain name or number

5. lavendulae; N.J. Agr. Exp. Station

S. lipmannii (Waksman \& Curtis, 1916) Waksman \& Henrici (1948); N.J.

Agr. Exp. Station

S. microflavus (Krainsky, 1914) Waksman \& Henrici (1948); CBS; A. Krainsky

S. odorifer (Rullmann, 1895) Waksman (1953); N.J. Agr. Exp. Station; Král Collection

S. parvullus Waksman \& Gregory (I954); F. J. Gregory, N.J. Agr. Exp. Station (G-375)

S. pravus (Krainsky, I9I4) Waksman \& Henrici (I948); R. G. Benedict,

U.S. Dept. Agr., Peoria, Ill. (NRRL B-I455)

S. praecox (Millard \& Burr, 1926) Waksman (I953); W. A. Millard, Univ. of Leeds

S. reticuli (Waksman \& Curtis, I9I6) Waksman \& Henrici (1948); N.J. Agr.

Exp. Station

* $S$. roseochromogenus (Jensen, 1931) Waksman \& Henrici (1948); R. W.

Thoma, E. R. Squibb and Sons, New Brunswick, N.J. (SC I624)

S. rutgersensis (Waksman \& Curtis, I9I6) Waksman \& Henrici (1948); N.J. Agr. Exp. Station

S. sampsonii (Millard \& Burr, I926) Waksman (1953); W. A. Millard

S. saprophyticus; N.J. Agr. Exp. Station

S. scabies (Thaxter, I 892) Waksman \& Henrici (1948); N.J. Agr. Exp. Station; M. Shapovalov (Morse I7)

S. scabies; CBS

S. scabies; ATCC (10246); W. H. Burkholder (N 54); R. W. Goss

S. setonii (Millard \& Burr, 1926) Waksman (1953); W. A. Millard

S. somaliensis; NCTC (3236); Wellcome Tropical Research Labs. (mycetoma)

S. sylvodoriferus; N.J. Agr. Exp. Station; ATCC (4919)

S. tetanusemus; N.J. Agr. Exp. Station; Pribram Collection

* S. vinaceus Waksman (1953); ATCC (1 I 86I); NRRL (B-2285)

S. viridis (Millard \& Burr, I926) Waksman (I953); W. A. Millard

S. viridis; R. W. Thoma (SC I633)

S. willmorei (Erikson, 1935) Waksman \& Henrici (1948); ATCC (6867); NCTC (1856); J. G. Willmore

Streptomyces sp.; C. C. Campbell, Army Med. Service Graduate School. Washington, D.C. (698)

Streptomyces sp.; T. G. Pridham, U.S. Dept. of Agr., Peoria, Ill. (D)

Streptomyces sp.; N.J. Agr. Exp. Station (I42)

Streptomyces sp.; R. L. Mayer, Ciba Pharmaceutical Co., Summit, N.J.

Streptothrix buccalis Goadby (I903); NCTC (4523); ATCC (33II); Pribram Collection

Streptothrix buccalis; N.J. Agr. Exp. Station; C.-E. A. Winslow

* Illegitimate specific epithet.

coloured, yellow, greenish yellow, olive drab or brown. Some cultures did not form aerial hyphae visible to the unaided eye; others showed patches or a thin coating of whitish aerial hyphae; still others were abundantly covered with greyish white or grey aerial hyphae. Soluble pigments were greenish yellow, greenish brown, reddish brown or red (Gordon \& Horan, I968, pl, 2).

Properties (Table 3) shared by all 46 reference strains of Streptomyces griseus, or those shared by a high percentage of the strains were: decomposition of adenine, casein, hypoxanthine, tyrosine, urea and xanthine; lack of growth at $45^{\circ}$; growth at $10^{\circ}$; survival after $8 \mathrm{hr}$ at $50^{\circ}$; use of citrate, lactate, malate and succinate as sole carbon source; failure to utilize benzoate, mucate or oxalate; sensitivity to lysozyme and 
Table 3. Pattern of reactions of Streptomyces griseus

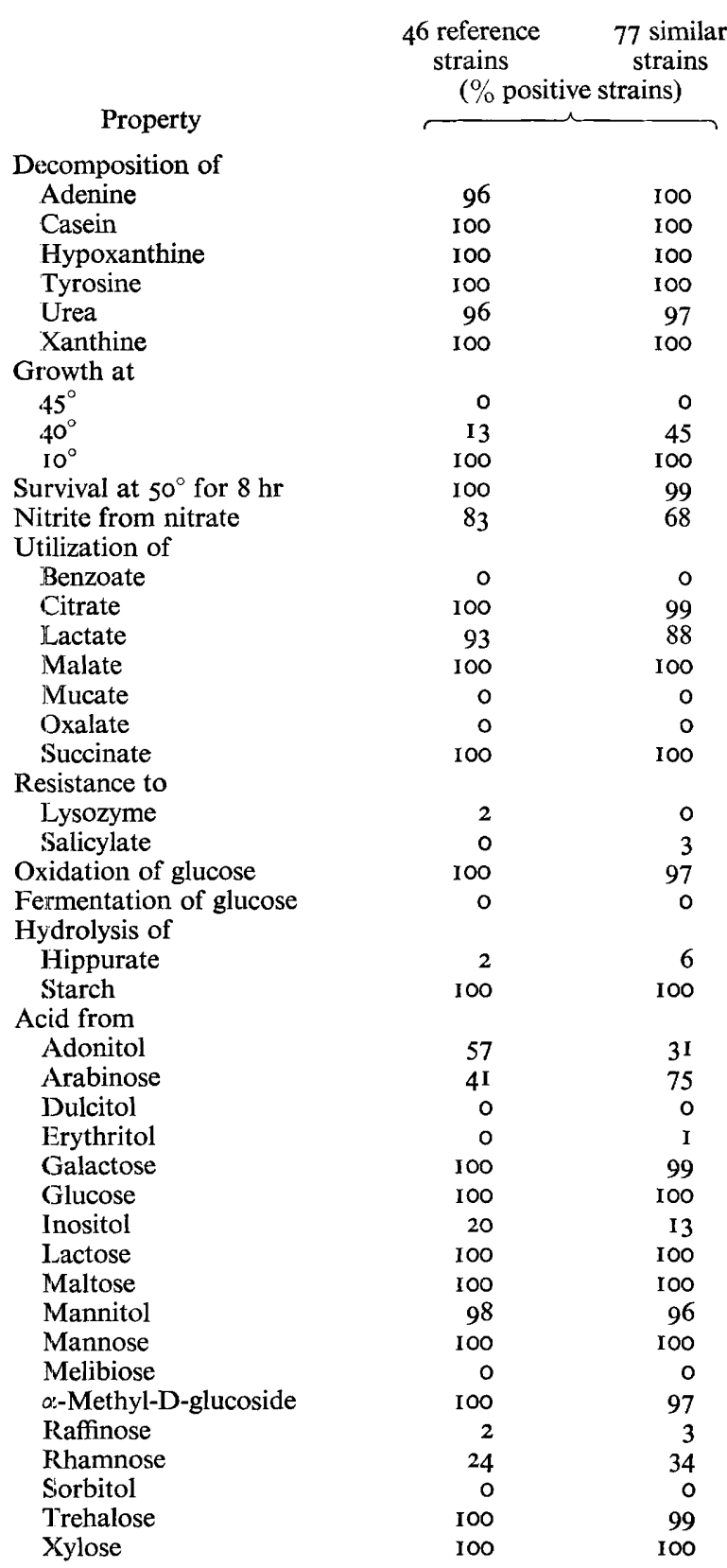

salicylate; oxidation of glucose; inability to form benzoic acid from hippurate; hydrolysis of starch; formation of acid from galactose, glucose, lactose, maltose, mannitol, mannose, $\alpha$-methyl-D-glucoside, trehalose and xylose; failure to attack dulcitol, erythritol, melibiose, raffinose or sorbitol. Variable characteristics of the 46 
Table 4. Comparison of properties of four species of streptomyces (\% positive strains)

\begin{tabular}{|c|c|c|c|c|}
\hline Property & $\begin{array}{c}\text { S. griseus } \\
\text { (I23 strains) }\end{array}$ & $\begin{array}{c}\text { S. albus } \\
\text { (23 strains) }\end{array}$ & $\begin{array}{l}\text { S. fradiae } \\
\text { (23 strains) }\end{array}$ & $\begin{array}{c}\text { S. somalien } \\
\text { sis } \\
\text { (22 strains) }\end{array}$ \\
\hline \multicolumn{5}{|l|}{ Decomposition of } \\
\hline Adenine & 98 & 4 & 100 & o \\
\hline Casein & 100 & 100 & 100 & 100 \\
\hline Hypoxanthine & 100 & 100 & 0 & 0 \\
\hline Tyrosine & 100 & 100 & 100 & 100 \\
\hline Urea & 97 & 100 & 0 & 0 \\
\hline Xanthine & 100 & 83 & o & 0 \\
\hline \multicolumn{5}{|l|}{ Growth at } \\
\hline $50^{\circ}$ & o & 100 & 0 & 0 \\
\hline $45^{\circ}$ & o & 100 & $9 I$ & 55 \\
\hline $40^{\circ}$ & 33 & 100 & 100 & 91 \\
\hline $10^{\circ}$ & 100 & 0 & 5 & 9 \\
\hline Survival at $50^{\circ}$ for $8 \mathrm{hr}$ & 99 & 100 & 91 & 50 \\
\hline Nitrite from nitrate & 73 & 60 & 100 & 0 \\
\hline \multicolumn{5}{|l|}{ Utilization of } \\
\hline Citrate & 99 & 100 & 0 & I 8 \\
\hline Lactate & 90 & 100 & 26 & 0 \\
\hline Maliate & 100 & 100 & 95 & 37 \\
\hline Mucate & 0 & 0 & 0 & 0 \\
\hline Oxallate & 0 & 57 & 0 & 0 \\
\hline Succinate & 100 & 100 & 100 & 45 \\
\hline \multicolumn{5}{|l|}{ Resistance to } \\
\hline Lysozyme & I & $2 I$ & 0 & 0 \\
\hline Salicylate & 2 & 100 & 0 & 0 \\
\hline Oxidation of glucose & 98 & 96 & IOO & 0 \\
\hline Fermentation of glucose & 0 & $4^{*}$ & 0 & 0 \\
\hline \multicolumn{5}{|l|}{ Hydrolysis of } \\
\hline Hippurate & 5 & 30 & 0 & 5 \\
\hline Starch & 100 & 0 & IOO & 36 \\
\hline \multicolumn{5}{|l|}{ Acid from } \\
\hline Adonitol & 43 & 100 & 0 & 0 \\
\hline Arabinose & 63 & 17 & 9 I & 0 \\
\hline Dulcitol & 0 & 0 & 0 & 0 \\
\hline Erythritol & I & 100 & 0 & 0 \\
\hline Galactose & 99 & 100 & 100 & 0 \\
\hline Glucose & 100 & 100 & 100 & 50 \\
\hline Inositol & 15 & 65 & 0 & 0 \\
\hline Lactose & 100 & 100 & 63 & 0 \\
\hline Maltose & IOO & 100 & 100 & 64 \\
\hline Mannitol & 97 & 100 & 0 & 0 \\
\hline Manınose & 100 & 100 & 100 & 5 \\
\hline Melibiose & 0 & 13 & 0 & 0 \\
\hline$\alpha$-Methyl-D-glucoside & 98 & 100 & 0 & 0 \\
\hline Raflìnose & 2 & 0 & 0 & 0 \\
\hline Rhamnose & 31 & 0 & 0 & 0 \\
\hline Sorbitol & 0 & 4 & 0 & 0 \\
\hline Trehalose & 99 & $9 I$ & 100 & 0 \\
\hline Xylose & 100 & 100 & 100 & 0 \\
\hline
\end{tabular}

reference strains were: growth at $40^{\circ}$; reduction of nitrate or nitrite; acid production from adonitol, arabinose, inositol, and rhamnose.

The following 2I strains (Tables I, 2) were found to contain $L L$-diaminopimelic acid: $3029,3068,3475,3523,3527,3567$ a, 3567 b, 3856, N3236, N 3258, N 4520, N 4523, 
N7808, 4I3,505,506, 5II, 638,676, 712 and 713. The IOI remaining strains of Streptomyces griseus were not tested for the form of diaminopimelic acid.

The reactions of the 77 strains listed in Table 2 are given in Table 3, and in Table 4 these reactions are combined with those of the 46 reference strains to represent one aggregate of Streptomyces griseus. The pattern of characters of these strains is compared (Table 4) with those of the strains in our collection of S. albus (RossiDoria) Waksman \& Henrici, S. fradiae (Waksman \& Curtis) Waksman \& Henrici and $S$. somaliensis (Brumpt) Waksman \& Henrici. As a group the following criteria served to differentiate this aggregate of $S$. griseus from the three other species of streptomycetes: decomposition of adenine, hypoxanthine, urea, and xanthine; growth at $10^{\circ}$ but not at $45^{\circ}$; use of citrate; sensitivity to salicylate; oxidation of glucose; hydrolysis of starch; acid production from galactose, lactose, mannitol, mannose, $\alpha$-methylD-glucoside, trehalose and xylose; and lack of acid formation from erythritol.

\section{DISCUSSION}

The usual practice of author citation of the name under which each strain was received was difficult to follow. After reading the available original descriptions of the species named in Table 2, we attempted to decide whether or not each strain was representative of its original strain. Because many of the descriptions of these strains relied on variable properties, and because of human fallibility in the preparation of descriptions and in the maintenance of cultures, the task proved to be impossible. We accepted, therefore, all strains whose authenticity was not definitely challenged either by the first description or by the recognition of very different strains as representatives of the particular species. For example, a strain deposited in this collection as Nocardia madurae and subsequently found to be Streptomyces griseus was obviously not typical of $N$. madurae, because other very different strains are accepted as representing N. madurae.

The names of the strains in Table 2 that are followed immediately and without intervening semicolon by the name of the author(s) are regarded as synonomous with Streptomyces griseus. Some of these strains came from the author(s) of the species. Other strains whose histories cannot be traced to the describer of the species may, however, be typical of the original strains, since they were found to possess characters that do not appear to be at variance with the original species descriptions.

Strain 3347 was accepted as conforming to Krainsky's (I9I4) description of Actinomyces roseus, although previously Namyslowski (I9I2) had given the name to another strain. In 1916, Chalmers \& Christopherson assigned Krainsky's A. roseus to the genus Nocardia. $N$. roseus has priority therefore over A. roseochromogenus, a name assigned to Krainsky's $A$. roseus by Jensen (I93I). The legitimate name for Krainsky's species is Streptomyces roseus (Chalmers \& Christopherson) Pridham, Hesseltine \& Benedict (I958). Mayer et al. (195I) named ATCCII86I S. vinaceus but did not describe it; the necessary description came from Waksman (1953). Although ATCC I I86I is considered as authentic, the name $S$. vinaceus is considered an illegitimate one for the species because Jones (195I) gave the name $S$. vinaceus to another strain.

Beijerinck (1912), cited by Waksman (1953), used the name Actinomyces (Streptothrix) annulatus, but since he did not describe the strain, his name has no nomenclatural 
status. Although Wollenweber (1920) ascribed the name to Krainsky, he gave no reference to the Krainsky work, and we have been unable to find it. Wollenweber (1920) also described and named some isolates of his own $A$. annulatus; in our opinion he was correctly cited by Hütter (1963) as the original author of the species name.

We are unable to give the authority for the name borne by ATCC 4879 , because this strain and strain 4878 were deposited in the ATCC in 1933 by S. A. Scudder and appear in the ATCC catallogue as Actinomyces candidus Petruschky (1903). Waksman (I953) assigned $A$. candidus Krassil'nikov (194I), which he did not regard the same as Streptothrix canalida Petruschky, to the genus Streptomyces and in 196I designated ATCC 4878 (IMRU 34I6) as the type strain of S. candidus (Krassil'nikov) Waksman.

Waksman (1953) cited Krüger (I809) as the author of Oospora intermedia, but Krüger did not mention this name in his report. Wollenweber (I920) named and described some isolations of his own as 'Actinomyces intermedius (Krüg.) Wr.' but did not identify Krüger's paper. Kudrina's (I957) and Pridham's (1964) listing of Wollenweber as the authority for the specific epithet is therefore in accord with the rules of nomenclature.

Actinomyces saprophyticus was named by Gasperini (1892); later Chalmers \& Christopherson (I916) assigned the same specific epithet to a species in the genus Nocardia. An authority for the transfer of either species to the genus Streptomyces was not found. A search of the literature did not reveal the author of the name and description of $N$. hemolytica, S. acidoresistans or S. tetanusemus. Strains labelled $N$. sylvodorifera and $S$. sylvodorifera could be traced to Castellani, but Castellani was unable to furnish the reference (personal communication), and the original characterization and naming of this species was not discovered.

Among the strains listed in Table 2, those labelled Actinomyces sulphureus, Nocardia asteroides, $N$. farcinica, N. madurae, Streptomyces albus, S. lavendulae and $S$. somaliensis were unlike recognized strains of these species and were therefore regarded as mis-named. Strain 4I3 was not accepted as representing $A$. keratolytica because Acton \& McGuire (193I) characterized their species as forming limpetshaped colonies, black or red in colour, with deep roots penetrating the media, and as resembling, in certain respects, cultures of $A$. bovis and $A$. madurae. ATCC 6855 was unacceptable as $N$. leishmani Chalmers \& Christopherson (I9I6), a species originally described as acicl-fast by Birt \& Leishman (I902).

A number of the strains listed in Table 2 were previously recognized as strains of Streptomyces griseus by Baldacci \& Comaschi (1956), Benedict et al. (1955), Burkholder, Sun, Anderson \& Ehrlich (I955), Ettlinger, Corbaz \& Hütter (I958), Hütter(I963) Krassil'nikov (1949), Pridham (1964), and others. Our findings, based mainly on different observations, support their conclusions.

The pattern of properties presented is for the identification of only one aggregate of strains of the heterogeneous species Streptomyces griseus and is not intended as a delination of the species. Strains labelled $S$. coelicolor, for example, which were recognized as $S$. griseus by Hütter (1963), Pridham (1964) and others, have, with three exceptions, the same pattern of characters. The three characters of strains of $S$. coelicolor not shared by the strains of this aggregate of $S$. griseus do not, however, offer a definite separation of the two groups, because other strains possess one or two of the three properties and are clearly intermediate. Other aggregates of strains of $S$. griseus are also represented in our collection and are bound together by inter- 
mediate strains. With the exception of the taxonomic group described here, the representation in our collection of the aggregates of $S$. griseus is inadequate, and we are unable to offer at this time a pattern of properties for the identification of the entire species.

This study was supported in part by research grant AI-06276 from the Public Health Service, Bethesda, Maryland, U.S.A., and by research grant GB-2579 from the National Science Foundation, Washington, D.C. U.S.A. We gratefully acknowledge this assistance and the kindness of Miss Emma C. Gergely, Librarian, in finding the reports needed for reference.

\section{REFERENCES}

Acton, H. W. \& McGuire, C. (193I). Actinomycotic lesions of the skin of the hands and feet, due to Actinomyces keratolytica, n.sp. Indian med. Gaz. 66, 65 .

Batrd-Parker, A. C. (Ig63). A classification of the micrococci and staphylococci based on physiological and biochemical tests. J. gen. Microbiol. 30, 409.

BaldaCCI, E. \& ComaschI, G. F. (I956). Contributo alla sistematica degli attinomicete. XVIII. Actinomyces griseus (Krainsky) Waksman. Mycopathol. Mycol. appl. 7, 279.

Becker, B., LecheValier, M. P., Gordon, R. E. \& Lechevalier, H. A. (I964). Rapid differentiation between Nocardia and Streptomyces by paper chromatography of whole-cell hydrolysates. Appl. Microbiol. 12, $42 \mathrm{I}$.

BeIJeRINCK, M. W. (I9I2). Mutation bei Mikroben. Folia microbiol. Delft $\mathbf{x}$, I.

Benedict, R. G., Pridham, T. G., Lindenfelser, L. A., Hall, H. H. \& Jackson, R. W. (1955). Further studies in the evaluation of carbohydrate utilization tests as aids in the differentiation of species of Streptomyces. Appl. Microbiol. 3, I.

BirT, C. \& LeISHMAN, W. B. (1902). A new acid-fast Streptothrix, pathogenic to man and animals. J. Hyg., Camb. 3, I20.

Burkholder, P. R., Sun, S. H., Anderson, L. E. \& Ehrlich, J. (1955). The identity of viomycinproducing cultures of Streptomyces. Bull. Torrey bot. Cl. 82, 108.

Castellani, A. \& Chalmers, A. J. (1913). Manual of Tropical Medicine, 2nd ed. New York: William Wood and Co.

Chalmers, A. J. \& Christopherson, J. P. (1916). A Sudanese actinomycosis. Ann. trop. Med. Parasit. 10, 223.

DuchÉ, J. (1934). Les actinomycés du groupe albus. Encycl. mycol. 6, 272.

ERIKSON, D. (1935). The pathogenic aerobic organisms of the actinomyces group. Spec. Rep. Ser. med. Res. Coun. No. 203.

EtTlinger, L., CoRbaz, R. \& HüTteR, R. (1958). Zur Systematik der Actinomyceten. 4. Eine Arteinteilung der Gattung Streptomyces Waksman et Henrici. Arch. Mikrobiol. 3r, 326.

GASPERINI, G. (I892). Ricerche morfologiche e biologiche sul genere Actinomyces-Harz come contributo allo studio delle relative micosi. Ann. Ist. Igiene sper. Univ. Roma 2, 167.

GoADBY, K. W. (1903). Mycology of the Mouth, p. 20I. London: Longmans, Green and Co.

Gordon, R. E. (1966). Some criteria for the recognition of Nocardia madurae (Vincent) Blanchard. J. gen. Microbiol. 45, 355.

Gordon, R. E. (1968). The taxonomy of soil bacteria. In The Ecology of Soil Bacteria. Ed. by T. R. G. Gray and B. Parkinson. Liverpool University Press. (In the Press.)

Gordon, R. E. \& Horan, A. C. (I968). Nocardia dassonvillei, a macroscopic replica of Streptomyces griseus. J. gen. Microbiol. 50, 235.

Gordon, R. E. \& Miнm, J. M. (1962). The type species of the genus Nocardia. J. gen. Microbiol. 27, I.

Hugh, R. \& Leirson, E. (1953). The taxonomic significance of fermentative versus oxidative metabolism of carbohydrate by various Gram negative bacteria. J. Bact. 66, 24 .

HÜTTER, R. (1963). Zur Systematik der Actinomyceten. IO. Streptomyceten mit griseus-Luftmycel. G. Microbiol. II, I91. 
JENSEN, H. L. (1931). Contributions to our knowledge of the Actinomycetales. II. The definition and subdivision of the genus Actinomyces, with a preliminary account of Australian soil actinomycetes. Proc. Linn. Soc. N.S.W. 56, 345.

JoNes, K. L. (I95I). A new streptomyces that produces vitamin $\mathrm{B}_{12}$ activity. Pap. Mich. Acad. Sci. 37, 47.

KoSER, S. A. (1924). Correlation of citrate utilization by members of the colon-aerogenes group with other differential characteristics and with habitat. J. Bact. 9, 59.

Krainsky, A. (1914). Die Aktinomyceten und ihre Bedeutung in der Natur. Zentbl. Bakt. Abt. 2, 4r, 649.

Krassil'nikov, N A. (I94I). Guide to the Actinomycetes, p. 38. Moscow: Akad. Nauk.

Krassil'nikov, N. A. (1949). Section Pertaining to Actinomycetes from Guide to the Identification of Bacteria and Actinomycetes. Trans. ed. by J. B. Routien. New York: Same Day Offset Co.

KrÜGER, R. (1890) Bakteriologisch-chemische Untersuchung käsiger Butter. Zentbl. Bakt. Abt. I, 7, $425,430,493$.

Kudrina, E. S. (1957). In Problems in the Classification of Antagonistic Actinomycetes. By G.F. Gauze, J. P. Preobrazhenskaya, E. S. Kudrina, N. O. Blinov, I. D. Ryabova and M. A. Sveshnikova, Trans. by G. Gottlieb. Washington: American Institute of Biological Sciences.

LindenBeIN, W. (1952). Über einige chemisch interessante Aktinomyceten-stämme und ihre Klassifizierung. Arch. Mikrobiol. 17, 36I.

Mayer, R. L., Cranje, C., DeBoer, C. J., Knopka, E. A., Marsh, J. S. \& Eisman, P. C. (i95i). Antibiotics from Act. vinaceus (nov.sp.). Microbiological studies. Abstr. Pap. XIIth int. Congr. pure appl. Chem. p. 283.

Millard, W. A. \& Burr, S. (1926). A study of twenty-four strains of Actinomyces and their relation to types of common scab of potato. Ann. appl. Biol. x3, 580 .

NAMYsLowski, B. (1912). Beitrag zur Kenntnis der menschlichen Hornhautbakteriosen. Zentbl. Bakt. Abt. 1, Originale 62, 564 .

Petruschky, J. (1903). Die pathogenen Trichomyceten--Streptothrix, Cladothrix, Leptothrix. In Handbuch der pathogenen Mikroorganismen. Ed. by W. Kolle and A. Wassermann, vol. 2, p. 833. Jena: Gustav Fischer.

Pridham, T. G. (1964). Taxonomic studies of Streptomyces griseus (Krainsky) Waksman et Henrici: A species comprising many sub-species. In Antimicrobial Agents and Chemotherapy... 1963, p. I04. Detroit: American Society for Microbiology.

Pridham, T. G., Hesseltine, C. W. \& Benedict, R. G. (I958). A guide for the classification of Streptomycetes according to selected groups: placement of strains in morphological section. Appl. Microbiol. 6, 52 .

Rossi-Doria, T. (I89I). Su di alcune specie di 'Streptotrix' trovate nell'aria studiate in rapporto a quelle già note e specialmente all 'Actinomyces'. Ann. Ist. Igiene sper. Univ. Roma r, 399.

RullmanN, W. (1895). Chemisch-bakteriologische Untersuchungen von Zwischendeckenfüllungen mit besonderer Berücksichtigung von Cladothrix odorifera. Zentbl. Bakt., Abt. I, I7, 884.

Spalla, C., Amici, A. M. \& Bianchi, M. L. (I96I). Descrizione di una nuova specie di Nocardia capace di formare un ossidrile in posizione 16 alfa in alcune steroidi. G. Microbiol. 9, 249.

Thaxter, R. (1892). Potato scab. Ann. Rep. Conn. agric. Exp. Sta. for I891, p. I 53.

Tsukamura, M. (1962). Differentiation of Mycobacterium tuberculosis from other mycobacteria by sodium salicylate susceptibility. Am. Rev. resp. Dis. 86, 8I.

Waksman, S. A. (I923). In Bergey's Manual of Determinative Bacteriology, Ist ed., p. 337. Soc. Amer. Bacteriologists. Baltimore: Williams and Wilkins Co.

Waksman, S. A. (1953). In Guide to the Classification and Identification of the Actinomycetes and their Antibiotics. S. A. Waksman and H. A. Le chevalier. Baltimore: Williams and Wilkins Co.

Waksman, S. A. (196I). The Actinomycetes, vol. 2. Baltimore: Williams and Wilkins Co.

Waksman, S. A. \& Curtis, R. E. (I9I6). The actinomyces of the soil. Soil Sci. 1, 99.

Waksman, S. A. \& Gregory, F. J. (I954). Actinomycin II. Classification of organisms producing different forms of actinomycin. Antibiotics Chemother. 4, I050.

Waksman, S. A. \& J.Henrici, A. T. (I948). In Bergey's Manual of Determinative Bacteriology, 6 th ed. Ed. by R.S. Breed, E. G. D. Murray and A. P. Hitchens, p. 929. Baltimore: Williams and Wilkins Co.

Wollenweber, H. W. (1920). Der Kartoffelschorf. Arb. ForschInst. Kartoff. Berlin 2, I. 
